\title{
Indonesian Government Bureaucracy Efforts to Prevent Covid-19 at the Beginning of the Pandemic Period
}

\author{
Zahrotunnimah Zahrotunnimah \\ Ufa State Petroleum Technological University, \\ 14, Pervomayskaya str., Ufa, Russian Federation, 450000 \\ zahrotunnimah@yahoo.com
}

\begin{abstract}
Since the World Health Organization declared the Corona Covid-19 virus as an epidemic, in the following, the Indonesian Government also stated that the Corona virus problem has become a non-natural national disaster. The President of the Republic of Indonesia and the Regional government together with their staff are helping one another in preventing the spread of Covid-19 in Indonesia. Many government bureaucratic efforts have been made by issuing policies as the initial steps to prevent the spread of Covid-19. As the implementer of the bureaucracy, the Government always strives to provide effective public services in efforts to prevent the spread of the Corona Covid-19 virus in society. From the central level to the heads of the provinces, Regencies and even the municipal governments. This study applies the content analysis method, in which the content analysis is limited to newspaper media which convey information related to some policies information presented by each head of government, both in several regions and countries. The purpose of this research is to provide education to the public in dealing with global disasters and efforts to prevent them. The results show that the bureaucratic efforts of the central government and local governments through various policies have carried out many communication strategies for their respective regional communities through coercion, informative, expulsion, targeting, persuasion and excess techniques in message packages in the form of instructions, to the public to prevent Covid-19 in their area. However, the techniques of coercion up to the approval stage are enforced to prevent the effect of violations on offenders. The central government in this case has not maximized its roles in implementing a comprehensive communication strategy for all local governments. This is due to the absence of the National Command from the central government which seems to be slow in preventing the transmission of Covid-19, which has become a global disaster, including in Indonesia.
\end{abstract}

Keywords: Government bureaucracy, Covid-19, Pandemic period, Indonesia

Conflicts of interest: The author declared no conflicts of interest.

Article history:

The article was submitted on 01.01.2021. The article was accepted on 20.02.2021.

For citation: Zahrotunnimah Z. Indonesian Government Bureaucracy Efforts to Prevent Covid-19 at the Beginning of the Pandemic Period. RUDN Journal of Public Administration. 2021; 8 (2): 153-166. DOI: $10.22363 / 2312-8313-2021-8-2-153-166$

(C) Zahrotunnimah Z., 2021

cc (i) This work is licensed under a Creative Commons Attribution 4.0 International License https://creativecommons.org/licenses/by/4.0/ 


\section{Introduction}

Indonesia is still struggling against the Corona virus at present, and so are the other countries in the world. The number of Corona virus cases continues to grow though some are reported to get recoveries, yet not few have died. The treatment and prevention efforts are continuously being implemented to fight COVID-19 which has similar symptoms to flu. The case of the Corona virus was identified by the discovery of a mysterious disease that paralyzed the City of Wuhan, China. The tragedy at the end of 2019 has continued to the spread of the Corona virus throughout the world.

The Corona virus Disease (Covid-19) outbreak is the most horrendous health issue in the whole world, including in Indonesia. The extreme countermeasures such as lockdown of an area and even a country are carried out in as an effort to minimize the spread of the disease [1]. When the news related to the corona virus was firstly broad casted, many countries panicked about the spread of the virus, but some responded casually to the corona virus outbreak. As a certain, this non-natural disaster is not the first time that countries in the world have ever faced [2]. History has recorded that there have been several viruses which were potentially also becoming life threatening when they were not well treated immediately, such as the Ebola, SARS, H5N1 or Bird Flu, HIV, MERS, and the others.

The new corona virus or COVID-19 has been declared as pandemic by the World Health Organization (WHO) and has political implications. One of them is how Chinese officials question the origin of the virus that has killed more than 4,200 people in the world. In this case, a number of Chinese netizens are also arguing about where COVID-19 actually was originated. WHO itself has confirmed that China was the first to report the presence of the virus in early January after cases emerged in Wuhan, Hubei Province. Of the 128,343 cases, 80,932 occurred in China. The United States and China have accused each other of the origin of the COVID-19 pandemic. President Donald Trump called it 'Chinese Virus', or the virus from China. Previously, a spokesman of the Chinese Ministry of Foreign Affairs, Zhao Lijian caused a commotion when he said, "it could be the US Army or US soldiers who brought the epidemic to Wuhan". The feud was confirmed in an interview with CNBC, US Minister of Foreign Affairs, Mike Pompeo was racist by calling COVID-19 the "Wuhan corona virus". Whereas WHO officially has emphasized that mentioning a region name to refer to a virus is something that is not allowed, as it is the potential to emerge a stigma and xenophobia which is very detrimental. However, US President Donald Trump has commented that COVID-19 is a "foreign virus". [3]

However, based on the results of research which was published in scientific journals, Nature Medicine defies the assumptions of China and Donald Trump's cohort, as well as refuting the conspiracy theory that says the virus which triggers Covid-19 or SARS-CoV-2 is man-made or a biological weapon that was deliberately created. As quoted from the website www.sciencedaily.com, Wednesday (18/3/2020), the results of the analysis of public data related to the genome sequence of SARS-CoV-2 and related viruses found no evidence that the virus was created in a laboratory. "By comparing the available genomic sequence 
data for known corona virus strains, we believe that SARS-CoV-2 originated from a natural process", said Kristian Andersen $\mathrm{PhD}$, associate professor of immunology and microbiology at Scripps Research, who co-authored the report. the study. Apart from Andersen, a number of other scientists also took part in the study and writing of a paper entitled, 'The proximal origin of SARS-CoV-2'. These include Robert F. Garry from Tulane University, Edward Holmes from the University of Sydney, Andrew Rambaut from the University of Edinburgh, and W. Ian Lipkin from Columbia University. Corona virus is a large family of viruses that could cause disease of wide severity [3].

In the 1960s, the first serious disease category, which was known to be caused by the Corona Virus, was Severe Acute Respiratory Syndrome (SARS) which began to become an epidemic in China in 2003. Meanwhile, the second disease categorization that broke out was Middle East Respiratory Syndrome (MERS) which started in Saudi Arabia in 2012. On December 31, 2019, Chinese authorities informed the World Health Organization (WHO) about the outbreak of a new corona virus that causes severe disease, which was later named SARS-CoV-2. Up to the present time, the virus has triggered the Covid-19 pandemic which has spread to all continents, except Antarctica. As of Wednesday 18 March 2020 at 18:33, there were 201,530 positive cases of the Corona Virus, 8,007 patients died, and the other of 82,034 recovered. The case widespread by the transmission occurs among humans. Shortly after the epidemic began, Chinese scientists sequenced the SARSCoV-2 genome and made data available for researchers around the world.

In this regard, Andersen and colleagues used the sequence data to explore the origin and evolution of SARS-CoV-2 with a focus on some of the distinctive features of the virus. Scientists meanwhile analyzed the genetic template for spike proteins, armatures, or the armour on the outside of the virus, which are used to capture and penetrate the outer walls of human and animal cells. More specifically, they focused on two important features of the spike protein: receptor-binding domain (RBD), a type of hook that attaches to the host cell, and the cleavage site that allows viruses to open gaps and enter the host cell [3].

For Indonesia, since Covid-19 was declared as a Pandemic period, by the World Health Organization (WHO), the Indonesian Government certainly has the responsibility to prevent the spread of Covid-19. As an implementer of the bureaucracy, of course they are required to be able to provide a very effective performance against the running of the government. Governance management is demanded for an effective bureaucratic system that prioritizes justice and the prosperity of its people. And to identify all the various complaints that are experienced by the community. Therefore, the important role of the bureaucracy is the most significant system to realize people's welfare [4]. There will certainly be a transition period from normal situation to the New Normal during the pandemic. In this case, the central and local governments in Indonesia as the implementer of the bureaucracy have be able to provide solutions and ways out in solving the problem which is being overwhelmed by the community. So that the community is able to experience the form of the development and changes significantly by the presence of the public services provided by the government as the implementer of the bureaucracy, especially in Indonesia [3]. 


\section{Research methods}

This research implements content analysis method. This method discusses in depth the contents of written or printed information in mass media. Content analysis is normally applied in qualitative research. There are several definitions regarding to the Content analysis. Content analysis in general could be defined as a method that includes all analysis of the content of the text, yet on the other hand content analysis is also practiced in describing a specific analytical approach. According to Holsti, the content analysis method is a technique to draw conclusions by identifying the specific characteristics of a message objectively, systematically and generally $[5 ; 6]$.

\section{Theoretical Review}

According to Weber, bureaucracy is the best organizational method in the form of specialization of tasks. In his book entitled easy in Sociology, power is a person's opportunity to build people's awareness of their own will [2].

Bureaucracy and Public Policy are not separated. Public policy is not instantly present without interference from the bureaucracy, on the other hand, public policy is not implementable by excluding bureaucratic activity. In the bureaucracy, there are parties in surround and involved, influence their activities in producing the policies $[7 ; 8]$.

The essence in the implementation of the bureaucracy as stated in the Law on Public Services Number 25 of 2009, in which in the provisions of the article 4 is that the bureaucracy should be able to present service to the community as follows: The first is the realization of clear boundaries and relationships concerning rights, responsibilities, obligations, and authorities in all parties related to the provision of public services. The second is the realization of proper public service delivery systems in accordance with the general principles of good governance and corporations. The third is the fulfillment of public service delivery in accordance with the applicable laws and regulations. The fourth is the realization of legal protection and certainty for the community in administering public services. Thus, as the implementer of the bureaucracy, the government is obliged to be able to provide a very effective performance during the administration of the government [9].

According to Anderson as quoted by Winarno [10], policy is a direction of action that has the purpose to be determined by an actor or a number of actors in overcoming problems and issues. Policies which are issued by the government are generally known as public policies. Dye [10] states that public policy concerns "whatever government chooses to do or not to do". This implies that public policy is any choice by the government, whether to do something or not to do something. Thus, this definition equates government policies in the forms of government actions and considers that every choice of action taken by the government certainly has goals and objectives to achieve [11].

The implementation of the government bureaucracy is inseparable from the communication strategies carried out in order to achieve the expected goals. A communication strategy could be interpreted as a guide and a communication planning (communication planning) and a communication management 
(communication management) to achieve a goal. To achieve its objectives, the communication strategy should be able to depict how tactical operations must be carried out. Meanwhile the approach depends on the different time, situation and conditions. Kulvisaechana [12; 13], It emphasizes what is meant by a communication strategy; which combine communication phases which covers communication frequencies, communication formalities, communication content, and communication channels. In so, the communication strategy is described as an effective planning in delivering messages, to be easily understood by the communicant and accept what has been conveyed, to change a person's attitude and behavior [14]. Furthermore, the definition of a communication strategy according to Rogers is a design to change human behavior on a large scale through the transfer of new ideas [9]. In this case it is obvious that the communication strategy is closely related to the goals to be achieved including the consequences (problems) which have been calculated, and also involves the planning how to achieve some of the consequences in accordance with the expected results or in accordance with the objectives $[15 ; 16]$.

There are several techniques which are applicable in communication strategies according to Arifin [8]: 1. Redundancy (Repetition). This technique is a way of influencing the audience by repeating the message to the audience. 2. Canalizing, is a technique by understanding and examining the influence of groups on individuals or audiences. 3. Informative, this technique is a form of a message that aims to influence the audience by providing information or explanation. 4. Persuasive. It is the technique of influencing by persuading. 5. Educative is a technique of an effort to influence the public from general statements made, which could be realized in the form of messages which contain opinions, facts, and experiences. 6. Coercive is a technique of influencing society by means of coercion. This technique normally manifests itself in the form of regulations, orders and intimidations.

\section{Research results and discussion}

Based on the results of searches from various newspaper media, especially in Indonesia at the beginning of the pandemic, there were several bureaucratic efforts taken by several regional heads in preventing the transmission of Covid-19 in the community by applying various communication strategies carried out. When the President of the Republic of Indonesia, Mr. Joko Widodo announced the measures to control the spread of Covid-19; which health experts considered it to be slow; the president as the head of government ordered regional heads from Provinces to districts and cities to determine the situation of the spread of Covid-19 in their region by consulting to National Disaster Management Agency (BNPB). By which the president's statement, was then followed by the determination of Indonesia is in a status of a national non-natural disaster of Covid-19 which has increased sharply in the last few days afterwards. The instructed steps of pandemic spread include: the learning and work process should be carried out in-house, and recommendation to postpone activities that involve large numbers of participants and carrying out testing for Covid-19 infection and treatment to maximally. (BBC News Indonesia, 
March 16 2020). The interesting thing is that, before there was a centralized appeal from the Indonesian government, in this case the President, several regional heads had previously taken the steps mentioned above. The regional government actions for the Covid-19 control initiatives have been carried out by the Provincial Government of DKI Jakarta, Solo City Government, Central Java Provincial Government and West Java Provincial Government.

\section{Bureaucratic Efforts of West Java Governor}

The bureaucratic effort carried out by the West Java Provincial government is to issue a policy of in-house learning by students and stopping mass activities. In early of February 2020, as the Governor of West Java, Mr. Ridwan Kamil set West Java to be on standby status, then built a West Java Covid-19 information and coordination centre that is available to be accessed by residents of West Java, took the initiative to conduct proactive tests or check samples which would be examined in the West Java Health Laboratory, in collaboration with the microbiology and parasitology laboratory of the Faculty of Medicine of Padjadjaran University and the Nano science and Nanotechnology Research Center Bandung Institute of Technology with WHO Bio safety Level 2 standards

\section{Bureaucratic Efforts of DKI Jakarta Governor}

In the midst of the outbreak of the Corona virus in Indonesia on March 11, 2020, the Governor of the Special Capital Region of Jakarta, Mr. Anis Baswedan, issued a policy to eliminate car free days, which were usually carried out on every Sunday on several protocol streets in Jakarta. This nullification would be effective in two weeks' time and would be re-evaluated in the future. Also appealed to the ranks of the provincial government who have symptoms of the corona virus to immediately report themselves. The DKI Provincial Government also postponed the performance of Formula E which would be held at Monas in June 2020. And also reminded to reduce physical contact between humans or social distancing. Then a few days later the DKI Jakarta provincial government imposed a ban on DKI residents of leaving Jakarta for the following three weeks. This prohibition was enforced as an effort to prevent the spread of the Cora Virus type 2 (SARS-CoV-2) which caused Covid-19. Specifically, the Governor of Jakarta, Anies Baswedan, during an internal meeting of the DKI Provincial Government at the DKI Jakarta Education Office Building on March 19, 2020, directly ordered the mayors, sub-district heads and administrativevillage heads to convey the prohibition to residents in their respective areas. He even emphasized that that staying at home is a form of state defense and as a contribution of citizens to prevent the spread of the Corona Virus.

\section{Bureaucratic efforts of Surabaya City Government}

When the President Joko Widodo issued the Presidential Decree 7 of 2020 concerning the task force to handle the Corona virus on March 13, 2020, the Bureaucratic Efforts of the Surabaya City Government, in this case Mrs. Risma, as the mayor of Surabaya on March 14, 2020, via the Surabaya City Education Office 
issued a form letter of policies to lay off PAUD, the children school (Early childhood education) and junior high school (SMP), change into in-house learning. To conduct a meeting with the Airlangga University Hospital in Surabaya concerning the prevention and handling of Covid-19, under the command of Mrs. Risma; Unit Civil Service Police, (Satpol pp) of Surabaya City were deployed to spray disinfectants in public places, schools and places of worship, such as mosques, churches, temples and monasteries. Mrs. Risma also opened a public kitchen at the Surabaya municipal Hall to provide herbal drinks of spices and boiled eggs; to distribute to the public in many administrative-villages and sub-districts in Surabaya area.

The mayor of Surabaya was working hard not to lock down Surabaya City, this move is considered to worsen the situation of the people of Surabaya. She mobilized all levels of the Surabaya City Government functionaries and adjusted to health protocols in carrying out the public services [17]. Mayor Risma also built hundreds of sinks in public places and public services surroundings, such as on many highways, in government offices, city parks etc. The number of sinks which were provided would increase as necessary. Through the construction of a sink, Mayor Risma has campaigned to Surabaya residents about the correct method of washing hands.

On March 16, 2020, the Mayor of Surabaya, Tri Rismaharini, held a coordination meeting with various stakeholders to prevent the transmission of the Covid-19 virus in Graha Sawung galing. The coordination meetings with various stake holders was to prevent the transmission of Corona Virus in Indonesia, especially in Surabaya. The coordination meeting was attended by transportation companies, businessmen in malls, hotels, entertainment business owners, and various other agencies in the city of Surabaya. She asked all stakeholders to apply the health protocol to prevent the corona virus or Covid-19 in their respective areas. This effort is crucial to suppress the transmission of the new corona virus or Covid19. Her officials also continue to conduct direct socializations to places of worship so that their administrators routinely keep the places clean, especially to clean floor and carpets to roll up. Regional heads at the level of the sub-district and administrative village have all gone down to socialize it.

In addition to the form letters distribution to all mosques and mini mosques administrators, the city government has also prepared a special website [18]. The site contains information or instructions on how to anticipate and fight the spread of Covid-19. Through this site, which is so called, Against COVID-19, the public is expected to know how to take steps to prevent and anticipate the spread of the corona virus as early as possible. In addition, Mrs. Risma was monitoring developments both domestic and in various other countries in handling COVID-19. One of them, she took the example of Vietnam in providing sterilization booths to fight the Corona CoVid-19 Virus. The country succeeded in fighting the Corona COVID-19 virus by providing examination booths or mobile decontamination chambers (MDCs) which were implemented in public places such as stations, terminals, malls and offices. In this case, the Surabaya government collaborated with the FIKOM College (Faculty of Communication Sciences) Surabaya for this set procurement. 


\section{Bureaucratic Efforts of East Java Governor}

The East Java Government Bureaucratic Efforts were carried out by the Governor of East Java Khofifah Indar Parawansa, namely by taking several policy steps in six fields to prevent the spread of the Covid-19 corona virus. The six fields are transportation, education, health, government, economics, and information communication. The decision was taken within 14 days from 16 to 29 March 2020. In these six areas, Khofifah emphasized the increasing awareness to prevent the corona pandemic. Among them is the transportation sector, which has been instructed to provide hand sanitizer and soap facilities in every public facility such as terminals, airports, stations and ports, to provide equipped health checkpoints with thermal guns and mouth masks. For the education sector, Khofifah issued a policy to instruct all school activities at all levels to be carried out in their respective homes by assigning assignments to be assessed when attending school [19]. Khofifah also mandated schools to postpone the implementation of student exchange activities (study exchange), both outside and inside the country, including study tour activities. Meanwhile, especially for SMK (vocational school)/ SMA (high school) that would take the national exam (UN) from March 16-19 2020, and SMA from March 30-April 2 2020, still it would be held according to schedule. However, the school was asked to pay attention to various health procedures that have been determined.

In the health sector, Khofifah instructed all health offices (Dinkes) in East Java to monitor people who have just arrived from other countries with the Corona virus. Then the health office must track patients who are declared positive for Coronavirus and increase counselling on prevention of Covid-19 to the public. Meanwhile, in the field of Information and Communication, Khofifah asked related parties to it to provide a Call Center, which has integrated numbers of 1500117 , 081334367800 (East Java Provincial Government Health Service), and 08124922279 (RSUD/ Local Public Hospital dr. Soetomo Surabaya). Especially for the community, they were also instructed to stay at home more and avoid crowds, except for urgent purposes. This is also in relation to the World Health Organization (WHO) which has declared Corona as a pandemic. So that efforts are needed to increase readiness to protect the East Java people's safety and health.

\section{Bureaucratic Efforts of the Central Java Governor}

Mr. Ganjar Pranowo, as the Governor of Central Java, has a policy by issuing a form letter, dated on Saturday, March 14, 2020; in regards to the increasing awareness of the Covid-19 infection transmission risks. It was addressed to regents or mayors, heads of regional officials, up level heads of agencies as well as all Central Java BUMN (State Business Agency) leaders. In his letter, the Governor of Central Java conveyed the need to prevent and control efforts through four steps, they are implementing coordination, socialization and education regarding to prevention and control efforts to the elements of society and business actors according to their authority. He conveyed that all agencies should take precautions as early as possible by providing various equipment and needs to check body conditions such as temperature detection devices, hand sanitizers and mouth masks 
for the sick to support the prevention and control efforts. As well as to ensure public places are clean and hygienic. In addition, Ganjar also instructed to postpone or limit activities that are presented by a large number of people in public places such as car free days areas, camping, study tours and so on. The fourth point of the form letter is the presence of an integrated information post in each agency. For this information, the Central Java provincial government opens a service of reporting and the Corona virus handling at the Central Java Province health office via telephone of 024-3580713. In addition, the Central Java provincial government has prepared 13 Reference Hospitals for Corona cases as of March 14, 2020.

\section{Bureaucratic Efforts of Solo Municipal Government}

The efforts of Solo City Government to act quickly to determine the status of the extraordinary occurrence (KLB) of the Corona virus or Covid-19 after the death of a positive Corona patient at the Dr.Moewardi Solo Hospital. The decision was taken when the Mayor of Solo, FX Hadi Rudy atmo, held a coordination meeting with the Regional Leaders Communication Forum (Forkominda) at the Solo Mayor's official residence on March 13, 2020. Then Solo city government issued a policy to eliminate Car Free Days which were routinely carried out on every Sunday morning at $06.00-09.00 \mathrm{WIB} /$ west Indonesia time standard; and this activity is left offto an undetermined time limit. Apart from that, he declared a policy for the education sector to inactivate schools starts from the elementary, junior high and madrasah/Islamic schools levels; they study at their respective homes instead, while excluded SMK and SMA for their exams period time. Art performances such as Wayang Sriwedari, Ketoprak (traditional drama) Balekambang were laid up as well. Various tourist destinations have been instructed to close and cancel several activities which would be held in Solo, such as Musrembang village competitions and the others. Not to mention the various sports activities at the Manahan stadium [20].

\section{Analysis of Local Government Bureaucratic Efforts in Implementing Communication Strategies in Prevention of Covid-19 at the start of the Pandemic}

It is riveting one's attention to learn how the government bureaucracy efforts by each regional head of government in Indonesia at the start of the pandemic [21]. More interestingly, most of them took policy earlier before any instructions or policies were issued by the president, in which the policies of the central government, especially in Indonesia, are considered to be sluggish. In fact, it could also be stated that there is not any national command, while the Corona Virus has been declared by WHO as a pandemic. The central government should respond to this as a national disaster. However, the dexterity of the provincial, district and city governmentsin carrying out their bureaucratic efforts to save their citizens in preventing the increasingly massive Covid- 19 by using a communication strategy to spread messages to the public in preventing Covid-19 transmission, could be a lesson.

Through his policy, the Governor of West Java, for example, applied coercive communication strategy techniques more dominantly than the others [22]. The communication strategy technique is carried out in the form of instructions to 
practice social distancing by closing car free days, dismissing schools in his area and also conducting Canalizing techniques, cooperating with hospitals and universities to work together in handling the prevention of Covid-19 transmission in the West Java region and also carrying out proactive and providing checks an information centre which are available to be accessed by residents regarding to the information and education in preventing the transmission of the Covid-19 virus. The level one alert determination status of COVID-19 for the West Java region was in early February

Similar to the West Java Provincial Government, the DKI Jakarta Provincial Government has also implemented a comprehensive policy in the form of the same instructions, they are eliminating car free days and instructing social distancing, closing recreational areas and clubs as places for people to gather, and cancelled activities to be held in June 2020. In addition, schools and universities were closed, and instructed people to work in-house. Performing the Canalizing technique, coordinating with the local city government, both the mayor and the sub-district head as well as the Lurah (the head of administrative village) to socialize to residents not to leave their homes. The Governor of DKI carried out the communication strategy also by applying a lot of coercive techniques in the form of instructions and educational messages as well, when he said that not leaving the house is a part of the form of State Defense, that could save the environment to prevent Covid-19 transmission to the wider community. This message certainly implies that the instructions given must be strictly obeyed by every citizen, because it would help all Indonesian people.

The policy which was carried out by the Mayor of Solo at the time of gathering the policy makers to socialize the cooperation in preventing Covid-19 transmission in the region, was to apply a lot of coercive communication strategies in the form of instructions and actions to shut down several places of activities which allowed many people to gather such as car free days; cease schools and regular art performances, implement a canalizing communication strategy. Likewise the Central Java provincial government practiced canalizing techniques and informative as well as educational, to provide the same understanding with the city government and its staff which was then followed by laying off all activities both teaching and learning activities, tourist attractions and providing information as well, through an information service centre to provide information educate the public regarding to the prevention of the Covid-19 Virus transmission in their environment.

The policy issued by Mrs. Risma, the mayor of Surabaya, was more tactical in carrying out the communication strategy. The first was the Coercive technique, by instructing to lay off teaching and learning activities in Surabaya, to carry out the Canalizing technique by gathering various stakeholders in Surabaya city area and inviting them to participate the joint movements to prevent Covid-19 transmission in their environment. In addition, she instructed to spray disinfectants, led by herself and provide a public kitchen to make herbal health drinks and food which were then distributed to residents as a means of public education. The time after time educational and persuasive communication strategies and informative were done by opening logs in appeal in grand educating the public to always keep cleanliness and make it as a habit to always wash their hands. In addition, providing 
sinks in public places which are easily to access for public and sterile booths as well; exemplifying how Vietnam provide these facilities so that the prevention of Covid-19 transmission could be minimized.

East Java Province by its policy applies more coercive communication strategies, in the form of instructions and socialization [23]. This means that the communication strategy carried out has also been in the form of informative and educative techniques. The canalizing strategy has also become dominant to deliver the messages in the prevention of Covid-19 transmission at the same time, especially in the province of East Java.

Based on the analysis above, it certainly becomes an evaluation material for all of us that a firm stance is needed in a situation like this considering that the disaster is not only a national disaster but also a global one. The whole world is still focusing on preventing the spread of Covid-19 in order not to spread widely.

It deserves to have policies or instructions, which are centralized from one command, for the status of the disaster is categorized as national and even global disaster. There should also be sanctions for those who violate them. It is very unfortunate, as a fact; at the present condition; that the commands are taken by each regional government with its limited scope of area and authority; in which it should have been accompanied by comprehensive actions from the central government. The central government could take strategic, appropriate and more comprehensive steps. By implementing the redundancy technique in controlling what the local governments do by one command. The central government could carry out the canalizing technique by monitoring the program efforts applied by each region, apply persuasive techniques to observe the efforts of the local government when they are not maximally implemented; practice informative and persuasive techniques and to always inform the development of the Corona Virus both domestic and abroad; implement educational techniques for all Indonesian people repeatedly and continuously; and use coercive techniques with sanctions; in concerning the massive transmission of Covid-19 in Indonesia.

Certainly, we also have a lot to learn from several other countries, how they also carry out their government bureaucratic efforts to protect the public from the massive spread of Covid-19. establishing cooperation among countries by putting aside egos and the dark past, for instance, three countries were known to have less harmonious relations due to the second world war, namely Japan-South Korea and China. History says that is the consequence of the second world war in which Japan once colonized the two countries, they get rid of their dark history for the sake of humanity. They put their respective egos aside and held a video conference to share information about the corona virus outbreak in their respective countries and discussed the ways to prevent further spread of the virus, while maintaining economic exchanges.

The results of the conference were quickly responded at the beginning of March 2020; South Korea immediately revoked the visa-free policy for migrants from Japan as a countermeasure where Japan had previously taken this policy to restrict the travel of its citizens to Korea which aimed at controlling the Corona virus pandemic, CoVid-19. The efforts which were made by the three countries are the right steps; however the Corona Virus is not only an enemy and a scourge which 
only needs to be discussed, but it needs real actions by each country to prevent the spread of the virus and also still consider the stability of their respective economy as well. This merely one of the portraits of 3 countries which could a lesson to take, that the ego and dark history could be defeated by the hope of saving the lives of millions of humans whom they must protect. The Corona case that hit the State Government of California, for example, has imposed a ban on leaving houses for all its citizens is an effort to stop the spread of the Covid-19 corona virus on March 19, 2020 local time.

As it is known that California is a home of 39 million people, the largest among the 50 states of the United States. It, so far, has been noted that the Corona Virus has killed 18 people there. Even Governor Gavin Newsom did not provide an illustration of how long the policy would be implemented for all citizens. However, the obedience of all citizens shows how much they pay attention to the impact of the virus and support the steps taken by the regional government as a form of citizen's support for a greater interest. Governor Gavin Newsom's policies were certainly not taken by excluding the coordination with the Federal government. The facts and solid data have put forward some compelling reasons by letter sent to President Donald Trump to send them assistance as in some parts of California the number of cases was doubling every four hours. About 56 percent of the population (25.5 million people) would be infected within eight weeks. The point is that every state action still needs to coordinate with the centre and convey authentic data about the findings in the field.

\section{Conclusion}

From some of the cases above, it could be concluded that the bureaucratic efforts of the Indonesian regional government which have been taken were in precision to protect their citizens in preventing Covid-19 at the beginning of the Pandemic period. Rapid actions could be taken by the governments of each region in preventing the spread of the Covid-19 Virus are correct, but the slow pace of the central government in taking command was very unfortunate. The role of the central government at that time seemed as if it only carried out a number of communication strategies and was not comprehensive, in the form of informative and coercive techniques which were still in the form of instructions without any sanctions to local governments. What we should understand is that the local government here also needs a guarantee, that the central government would provide assistance to each region when something happens and could not be resolved by the local government. The central government should be ready to carry out a national command and provide security and safety guarantees for all Indonesian citizens.

\section{REFERENCES}

[1] Anisa S. Sejarah Asia Timur: Dari masa Peradaban kuno hingga modern. Yogyakarta: Penerbit Sociality. Yogyakarta : Sociality; 2017 (In Indon.).

[2] Arifin A. Strategi Komunikasi. Bandung: CV. Amrico; 1994 (In Indon.).

[3] BBC News. Indonesia. URL: https://www.bbc.com/indonesia/indonesia-51232803. Accessed: 15.01.2020. (In Indon.) 
[4] Setiawan R., Melinda E. Optimization of the Implementation of Village Government in Indonesia. RUDN Journal of Public Administration. 2020; 7 (4). DOI: 10.22363/23128313-2020-7-4-352-360

[5] Setiawan R. Partisipasi Publik Dalam Program Bantuan Listrik Pedesaan Masyarakat Kabupaten Mesuji. Jurnal e-JKPP. 2017; 3 (3): 82-92 (In Indon.).

[6] Setiawan R. Peranan Etika Aparatur Sipil Negara Dalam Pelayanan Publik Pada Dinas Kependudukan Dan Catatan Sipil (Disdukcapil) Kota Bandar Lampung. Jurnal e-JKPP. 2016; 2 (2): 46-57 (In Indon.).

[7] Budiman S. Analisis Hubungan Antara Hukum dan Kebijakan Publik :Studi Pembentukan UU No . 14 tahun 2008 ( Analysis of Relation Between Law and Public Policy: Abstrak. Jurnal Ilmiah Kebijakan Hukum 2008. 2017; (14): 109-19 (In Indon.).

[8] Fatkhuri F. Korupsi Dalam Birokrasi Dan Strategi Pencegahannya. Jurnal Ilmiah Manajemen Publik dan Kebijakan Sosial. 2018; 1 (2). DOI: 10.25139/jmnegara.v1i2.784 (In Indon.).

[9] Cangara H.H. Perencanaan dan strategi Komunikasi. Jakarta: PT. Raja GrafindoPersada; 2013 (In Indon.).

[10] Dye T.R. Memahami Kebijakan Publik. Yogyakarta: Gajah mada University Press; 1981 (In Indon.).

[11] Damanik I. Otonomi Daerah, Etnonasionalisme, dan Masa Depan Indonesia. Jakarta: Yayasan Obor Indonesia; 2012 (In Indon.).

[12] Herdiana D. Sosialisasi Kebijakan Publik: Pengertian dan Konsep Dasar. Jurnal Ilmiah Wawasan Insan Akademik. 2018; 1 (3): 13-26 (In Indon.).

[13] Holsti O.R. Content Analysis for The Social Science and Humanities. Massachusetts: Addison-Westley Publishing; 1969.

[14] Effendy O.U. Ilmu Komunikasi: Teori dan Praktek. Bandung: remajarosdakarya; 2011 (In Indon.).

[15] Farida I., Setiawan R., Maryatmi A.S., Juwita M.N. The Implementation of E-Government in The Industrial Revolution Era 4.0 in Indonesia. International Journal of Progressive Sciences and Technologies. 2020; 22 (2). DOI: 10.47494/ijpst.v22.2.2165

[16] Rakhmat J. Metode Penelitian Komunikasi. Bandung: CV. RemajaRosdakarya; 1994 (In Indon.).

[17] Setiawan R. Evolution of Tatarstan's Local Self-Governments and Challenges They Face. 'ADALAH. 2019; 3 (5). DOI: 10.15408/adalah.v3i5.17936 (In Indon.).

[18] Setiawan R., Abdurahman A., Pertiwi P.G., Saputri S. Reaksi Perekonomian Rusia Ditengah Pandemi Covid-19. 'Adalah. 2020; 4 (1). DOI: 10.15408/adalah.v4i1.17935 (In Indon.).

[19] Setiawan R., Sulthan M. F., Abdurrahman A. Government Policy in Public Services in the Republic of Tatarstan, Russia. Jurnal Cita Hukum. 2020; 8 (3). DOI: 10.15408/jch.v8i3.17950

[20] Setiawan R., Pertiwi G.P., Faizah S.I.N. Ethnocultural Problems and Policies in The Republic of Tatarstan, Russia. Jurnal Socius: Journal of Sociology Research and Education. 2020; 7 (2). DOI: 10.15408/siclj.v4i2.18220

[21] Setiawan R., Faizah S.I.N., Pertiwi G.P. Manajemen Sistem Registrasi Penduduk Asing Melalui Elektronik Digital di Rusia. EXPERT: Jurnal Manajemen Sistem Informasi dan Teknologi. 2020; 10 (2). DOI: 10.36448/jmsit.v10i2.1555 (In Indon.).

[22] Sumaryana A. Birokrasi Dan Pelayanan Publik. Jurnal Sosiohumaniora. 2005; 7 (2): $133-142$ (In Indon.).

[23] Winarno B. Teori dan Proses Kebijakan Publik. Yogyakarta: Medpress; 2002 (In Indon.).

\section{Information about the author:}

Zahrotunnimah Zahrotunnimah - PhD Student of Political Science, Ufa State Petroleum Technological University (Russian Federation) (ORCID ID: 0000-0002-6412-8690) (e-mail: zahrotunnimah@yahoo.com). 


\title{
Усилия правительственного аппарата Индонезии по предотвращению Covid-19 в начальный период пандемии
}

\author{
3. Захротуннимах \\ Уфимский государственный нефтяной технический университет, \\ 450000, Россия, Уфа, Первомайская ул., 14 \\ zahrotunnimah@yahoo.com
}

\begin{abstract}
Аннотация. Поскольку в 2020 году Всемирная организация здравоохранения объявила об эпидемии Covid-19, правительство Индонезии также заявило, что проблема вируса стала неестественным национальным бедствием. С этого момента Президент Республики Индонезия и региональное правительство работают сообща для предотвращения распространения Covid-19 в стране. Правительством был принят ряд мер для выпуска медицинских полисов в качестве начальных шагов по предотвращению распространения Covid-19. Правительство Индонезии как исполнитель решений высшего политического руководства страны стремится предоставлять эффективные общественные услуги в рамках усилий по предотвращению распространения вируса Covid-19 в обществе от центрального уровня до глав провинций, округов и даже муниципальных органов власти. В этом исследовании применяется метод контент-анализа, при котором контент-анализ ограничивается газетными СМИ, которые передают информацию о политике, представленной главами правительств как на региональном, так и на национальном уровнях. Результаты исследования показывают, что усилия аппарата центрального правительства и местных органов власти посредством различных информационных и регулятивных политик позволили реализовать множество коммуникационных стратегий для соответствующих региональных сообществ, позволивших предотвратить предотвратить распространение Covid-19 в конкретных районах. Однако применяются и методы принуждения, в том числе и для того, чтобы уберечь самих правонарушителей. При этом центральное правительство не максимизировало свою роль в реализации всеобъемлющей коммуникационной стратегии для всех местных органов власти. Это связано с отсутствием последовательного планирования в центральном правительстве, которое, похоже, запаздывает в борьбе с коронавирусом, пандемия которого стала глобальной катастрофой, в том числе в Индонезии.
\end{abstract}

Ключевые слова: правительственный аппарат, Covid-19, период пандемии, Индонезия

Заявление о конфликте интересов: Автор заявляет об отсутствии конфликта интересов.

Благодарности: Автор благодарит Школу менеджмента Секола Тингги, DKI Джакарта, Индонезия, за поддержку этого исследования.

\section{История статьи:}

Статья поступила в редакцию: 01.01.2021. Статья принята к публикации: 20.02.2021.

\section{Для цитирования:}

Zahrotunnimah Z. Indonesian Government Bureaucracy Efforts to Prevent Covid-19 at the Beginning of the Pandemic Period // Вестник Российского университета дружбы народов. Серия: Государственное и муниципальное управление. 2021. Т. 8. № 2. С. 153-166. DOI: 10.22363/2312-8313-2021-8-2-153-166

\section{Информация об авторе:}

Захротуннимах Захротуннимах - аспирант-политолог, Уфимский государственный нефтяной технический университет, Россия (ORCID ID: 0000-0002-6412-8690) (e-mail: zahrotunnimah@yahoo.com). 